\title{
Adjuvant Taxanes in Breast Cancer: A Critical Re-appraisal
}

\author{
Alfonso Sánchez-Muñoz, Nuria Ribelles, Emilio Alba \\ ${ }^{1}$ Medical Oncology Department, Hospital Clínico Universitario Virgen de la Victoria, Málaga. Spain. \\ Email: asmoncomed@yahoo.es
}

Received March 13 ${ }^{\text {th }}, 2011$; revised May 12 ${ }^{\text {th }}, 2011$; accepted May 23 ${ }^{\text {rd }}, 2011$.

\begin{abstract}
Purpose: Several studies have reported a positive impact for taxanes in adjuvant breast cancer (BC) treatment in terms of reduced recurrence and mortality. However the impact of the magnitude on overall survival (OS) remains partially controversial. Methods: We examined the impact of taxane-containing adjuvant therapy for patients with early BC on OS, based on the number of deaths and on the calculated number of patients who need to be treated with taxanes to avoid one death (NNT). We classified patients in three different groups according to whether taxanes were administered concurrently or sequentially, and whether all treatment arms had the same or different duration. Results: 1) Taxanes in combination therapy: 8258 patients (4373 with taxanes and 3885 without taxanes), with 723 OS events. Overall survival for taxane-treated patients was $92.7 \%$ versus $89.6 \%$ for patients not receiving taxanes. NNT was 33. 2) Sequential treatment of unequal duration in the treatment arms: 14,228 patients (7970 with taxanes and 6256 without). Overall survival in taxane-treated patients was $86 \%$ compared with $83.2 \%$ for patients not receiving taxanes. NNT was 44.3 ) Sequential treatment and similar duration in treatment arms: 9511 women (5093 with taxanes and 4418 without). Overall survival in patients treated with taxanes was $87 \%$ versus $85 \%$ in patients not receiving taxanes. NNT was 50 . When the results of all these trials were considered together, the NNT stands at 43 patients. Conclusion: Taxanes afford a modest increase in overall survival in BC patients regardless of how they are given. Translational trials may well help to improve patient selection in the future.
\end{abstract}

Keywords: Taxanes, Adjuvant Chemotherapy, Early Breast Cancer

\section{Introduction}

Several metanalyses [1,2] have reported a positive impact for taxanes in adjuvant breast cancer treatment in terms of reduced recurrence rates and mortality. This reduction was seen regardless of either the kind of taxane used (paclitaxel versus docetaxel), the administration schedule (concurrent versus sequential) in combination with other chemotherapy agents such as the anthracyclines, duration in treatment time (same duration versus differing duration) for chemotherapy regimens in the taxane and control arms, axillary node involvement and hormone receptor status. Some of the published studies [3-12], though not all [13-20], showed an increase in disease-free survival. Furthermore, only in a few of these studies $[3,6,7,11]$ there were higher overall survival, while the impact of the magnitude on overall survival remains partially controversial. This information calls for a re-appraisal of the issue of which patient sub-groups really benefit from the addition of taxanes in adjuvant breast cancer therapy.

\section{Methods and Results}

We have examined the impact of taxane-containing adjuvant therapy for patients with early breast cancer on overall survival, based on the number of deaths occurring in the different treatment arms and on the calculated number of patients who need to be treated with taxanes to avoid one death (NNT). We classified patients in three different groups of study according to whether the taxanes were administered concurrently or sequentially, and whether all treatment arms had the same or different duration. In all, we reviewed outcomes for 31,997 patients recruited in 18 Phase III clinical trials. There were 7729 DFS events and 4205 OS events.

The first group included patients from clinical trials using taxanes in combination therapy (Table 1). In all, there were 8258 patients (4373 with taxanes and 3885 without taxanes) from 6 clinical trials, with 723 OS events. Overall survival for taxane-treated patients was 
Table 1. Clinical trials with taxane-combination therapy in the adjuvant treatment of early breast cancer.

\begin{tabular}{|c|c|c|c|c|c|c|c|}
\hline Trial ( $n^{\circ}$ patients) & N status & $\begin{array}{l}\text { Follow up } \\
\text { (months) }\end{array}$ & Design & $\begin{array}{l}\text { HR for DFS } \\
\text { ( } p \text { value })\end{array}$ & $\begin{array}{l}\text { Events } \\
\text { for DFS }\end{array}$ & $\begin{array}{l}\text { HR for OS } \\
\text { (p value) }\end{array}$ & $\mathbf{N}^{\circ}$ deaths \\
\hline Anglo-Celtic, $2005(363)^{13}$ & $+1-$ & 32 & $\begin{array}{l}\mathrm{AD}(183) \\
\mathrm{AC}(180)\end{array}$ & $\begin{array}{c}\text { NR } \\
(0.20)\end{array}$ & $\begin{array}{l}45 \\
55\end{array}$ & $\begin{array}{c}\text { NR } \\
(0.57)\end{array}$ & $\begin{array}{l}25 \\
28\end{array}$ \\
\hline BCIRG 001, $2005(1491)^{3}$ & + & 55 & $\begin{array}{l}\text { TAC (745) } \\
\text { FAC (746) }\end{array}$ & $\begin{array}{c}0.72 \\
(0.001)\end{array}$ & $\begin{array}{l}172 \\
227\end{array}$ & $\begin{array}{c}0.7 \\
(0.008)\end{array}$ & $\begin{array}{c}91 \\
130\end{array}$ \\
\hline E2197, $2008(2882)^{14}$ & $+/-$ & 79.5 & $\begin{array}{l}\text { AD (1441) } \\
\text { AC (1441) }\end{array}$ & $\begin{array}{l}1.02 \\
(0.78)\end{array}$ & $\begin{array}{l}257 \\
262\end{array}$ & $\begin{array}{l}1.06 \\
(0.62)\end{array}$ & $\begin{array}{l}116 \\
123\end{array}$ \\
\hline BIG 02-98, $2008(1446)^{4}$ & + & 62,5 & $\begin{array}{l}\mathrm{AD} \rightarrow \mathrm{CMF}(959) \\
\mathrm{AC} \rightarrow \mathrm{CMF}(487)\end{array}$ & $\begin{array}{c}0.86 \\
(0.05)\end{array}$ & $\begin{array}{l}252 \\
137\end{array}$ & $\begin{array}{l}0.92 \\
(\mathrm{~ns})\end{array}$ & $\begin{array}{l}6 \\
4\end{array}$ \\
\hline $\begin{array}{l}\text { GEICAM 9805, } 2008 \\
(\mathbf{1 0 6 0})^{5}\end{array}$ & - & 77 & $\begin{array}{l}\text { TAC (539) } \\
\text { FAC (521) }\end{array}$ & $\begin{array}{c}0.68 \\
(0.014)\end{array}$ & $\begin{array}{l}66 \\
95\end{array}$ & $\begin{array}{c}0.76 \\
(0.29)\end{array}$ & $\begin{array}{l}24 \\
34\end{array}$ \\
\hline US Oncology, $2009(1016)^{6}$ & $+/-$ & 84 & $\begin{array}{l}\mathrm{DC}(506) \\
\mathrm{AC}(510)\end{array}$ & $\begin{array}{c}0.74 \\
(0.033)\end{array}$ & $\begin{array}{c}88 \\
118\end{array}$ & $\begin{array}{c}0.69 \\
(0.032)\end{array}$ & $\begin{array}{l}58 \\
84\end{array}$ \\
\hline
\end{tabular}

A: doxorubicin. C: cyclophosphamide. D: docetaxel. F: fluorouracil. P: paclitaxel. E: epirubicin. M: methotrexate. OS: overall survival. DFS: disease free survival. HR: hazard ratio. NS: not significant. NR: not reported.

$92.7 \%$ versus $89.6 \%$ for patients not receiving taxanes. NNT was 33 patients.

The second group assessed patients recruited on clinical trials using sequential treatment of unequal duration in the different treatment arms (Table 2). In all, we studied 14,228 patients (7970 with taxanes and 6256 without) from 9 clinical trials, although we were unable to examine OS survival data in two of these (MD Anderson and ECTO trials). Overall survival in taxane-treated patients was $86 \%$ compared with $83.2 \%$ for patients not receiving taxanes, with an NNT of 44 patients.

The third group included patients from clinical trials with sequential treatment and similar duration in all treatment arms (Table 3). In all, 9511 women from 4 clinical trials (5093 with taxanes and 4418 without) were assessed. Overall survival in patients treated with taxanes was $87 \%$ versus $85 \%$ in patients not receiving taxanes. NNT was 50 patients in this case.

When the results of all these trials are considered together, the NNT stands at 43 patients.

\section{Discussion}

This result reflects how only a small number of taxane-treated breast cancer patients actually improve overall survival with adjuvant taxanes. This leads us to wonder which patient population may really benefit from this therapy.

Currently there are no clearly defined prognostic factors for the efficacy of taxanes in adjuvant therapy for early breast cancer with positive or high risk negative axillary lymph nodes. Attempts have been made to link taxane benefits with hormone receptor and Her2 expression in the tumor. In some trials, there was a greater gain from taxanes in patients with hormone-receptor negative tumours $[4,7,14,15,16]$, than in receptor positive cancers.

A retrospective study conducted by CALGB from 3 randomised trials (CALGB 8541, CALGB 9344/INT0148,
CALGB 9741), compared the benefit of adjuvant chemotherapy in 6.644 patients with early, lymph-node positive breast cancer between estrogen-receptor positive tumours versus estrogen-receptor negative tumours. The absolute benefit of the optimal chemotherapy regimen (dose-dense chemotherapy in the third study versus suboptimal dose in the first study) was greater in estrogen-receptor negative (ER-) cancers than in estrogen-receptor positive $(\mathrm{ER}+)$ cases, with a difference in 5 -year DFS of $22.8 \%$ for ER- tumours versus $7 \%$ for $\mathrm{ER}+$. There were also greater differences in OS for ERtumours, namely, $16.7 \%$ versus $4 \%$ for ER+. In all three studies, the gain was greater in ER- than in ER+ tumours from the best chemotherapy regimen [21]. However, this does not mean that hormone receptor positive tumours may or should forgo the benefits of taxanes even though their impact may be more limited in this kind of cancer.

Other research groups have failed to find any difference in hormone receptor expression status and benefit from taxanes $[3,6,8,12,17,20]$. Moreover, the results of the metanalyses $[1,2]$ found no difference in taxane benefit according to hormone receptor status either, in spite of the fact that most trials studied included similar hormone therapy policies, where tamoxifen was given for 5 years in patients with ER+/PR+ cancer, with only some exceptions. The HeCOG trial [16] included LHRH agonists in their hormone therapy for 1 year together with tamoxifen for pre-menopausal women with positive hormone receptors. The ECTO trial [9] treated all their patients with tamoxifen up to June 2000; after that time, tamoxifen was given only to women with positive hormone receptor status. In the NSABP B-28 trial [8] all women over 50 years of age received tamoxifen regardless of receptor status, while women aged $<50$ years only received tamoxifen if hormone receptor positive. In this study, tamoxifen was also given concurrently with chemotherapy which may lessen the efficacy of chemotherapy. In the PACS 01 trial [11], initially only post-meno- 
Table 2. Clinical trials in the adjuvant treatment of early breast cancer using taxanes sequentially and with unequal duration.

\begin{tabular}{|c|c|c|c|c|c|c|c|}
\hline Trial ( ${ }^{0}$ patients) & $\begin{array}{c}\mathrm{N} \\
\text { status }\end{array}$ & $\begin{array}{c}\text { Follow up } \\
\text { (months) }\end{array}$ & Design & $\begin{array}{l}\text { HR for DFS } \\
\text { ( } p \text { value })\end{array}$ & $\begin{array}{l}\text { Events } \\
\text { for DFS }\end{array}$ & $\begin{array}{c}\text { HR for OS } \\
\text { (p value) }\end{array}$ & $\mathbf{N}^{\circ}$ deaths \\
\hline $\begin{array}{c}\text { MD Anderson, } 2002 \\
(524)^{15}\end{array}$ & $+/-$ & 60 & $\begin{array}{l}\text { P } \rightarrow \text { FAC (265) } \\
\text { FAC (259) }\end{array}$ & $\begin{array}{c}0.7 \\
(0.09)\end{array}$ & $\begin{array}{l}39 \\
53\end{array}$ & NR & $\begin{array}{l}23 \\
24\end{array}$ \\
\hline $\begin{array}{c}\text { CALGB 9344, } 2003 \\
(3121)^{7}\end{array}$ & + & 69 & $\begin{array}{c}\mathrm{AC} \rightarrow \mathrm{P}(1551) \\
\mathrm{AC}(1570)\end{array}$ & $\begin{array}{c}0.83 \\
(0.002)\end{array}$ & $\begin{array}{l}491 \\
563\end{array}$ & $\begin{array}{c}0.82 \\
(0.006)\end{array}$ & $\begin{array}{l}342 \\
400\end{array}$ \\
\hline He COG, $2005(595)^{16}$ & $+1-$ & 62 & $\begin{array}{c}\mathrm{E} \rightarrow \mathrm{P} \rightarrow \mathrm{CMF}(297) \\
\mathrm{E} \rightarrow \mathrm{CMF}(298)\end{array}$ & $\begin{array}{l}0.93 \\
(0.55)\end{array}$ & $\begin{array}{l}91 \\
98\end{array}$ & $\begin{array}{l}\text { NR } \\
(0.38)\end{array}$ & $\begin{array}{l}53 \\
61\end{array}$ \\
\hline NSABP-B28, $2005(3060)^{8}$ & + & 64 & $\begin{array}{c}\mathrm{AC} \rightarrow \mathrm{P}(1529) \\
\mathrm{AC}(1531)\end{array}$ & $\begin{array}{c}0.83 \\
(0.006)\end{array}$ & $\begin{array}{l}400 \\
463\end{array}$ & $\begin{array}{c}0.93 \\
(0.46)\end{array}$ & $\begin{array}{l}243 \\
255\end{array}$ \\
\hline NSABP B27, $2006(2404)^{17}$ & $+1-$ & 77.9 & $\begin{array}{c}A C \rightarrow S \rightarrow D(799) \\
A C \rightarrow D \rightarrow S(803) \\
A C \rightarrow S(802)\end{array}$ & $\begin{array}{c}0.9 \\
(0.24)\end{array}$ & $\begin{array}{l}254 \\
260 \\
276\end{array}$ & $\begin{array}{l}1.08 \\
(0.51)\end{array}$ & $\begin{array}{l}171 \\
156 \\
157\end{array}$ \\
\hline TAXIT 216, $2006(972)^{18}$ & + & 53.6 & $\begin{array}{c}\mathrm{E} \rightarrow \mathrm{D} \rightarrow \mathrm{CMF}(486) \\
\mathrm{E} \rightarrow \mathrm{CMF}(486)\end{array}$ & $\begin{array}{c}0.79 \\
(0.057)\end{array}$ & $\begin{array}{l}115 \\
138\end{array}$ & $\begin{array}{c}0.72 \\
(0.08)\end{array}$ & $\begin{array}{l}51 \\
70\end{array}$ \\
\hline BIG 02-98, $2008(1441)^{4}$ & + & 62.8 & $\begin{array}{c}\mathrm{A} \rightarrow \mathrm{D} \rightarrow \mathrm{CMF}(960) \\
\mathrm{A} \rightarrow \mathrm{CMF}(481)\end{array}$ & $\begin{array}{c}0.86 \\
(0.05)\end{array}$ & $\begin{array}{l}214 \\
129\end{array}$ & $\begin{array}{l}0.92 \\
(\mathrm{~ns})\end{array}$ & $\begin{array}{l}3 \\
7\end{array}$ \\
\hline ЕСТО, $2009(1355)^{9}$ & $+/-$ & 76 & $\begin{array}{c}\mathrm{AT} \rightarrow \mathrm{CMF} \rightarrow \mathrm{S}(451 \\
\mathrm{S} \rightarrow \mathrm{AT} \rightarrow \mathrm{CMF}(451) \\
\mathrm{S} \rightarrow \mathrm{A} \rightarrow \mathrm{CMF}(453)\end{array}$ & $\begin{array}{c}0.73 \\
(0.03)\end{array}$ & NR & $\begin{array}{c}0.8 \\
(0.21)\end{array}$ & NR \\
\hline HORG, $2010(756)^{10}$ & + & 62.5 & $\begin{array}{l}\mathrm{D} \rightarrow \mathrm{EC}(378) \\
\text { FEC (378) }\end{array}$ & $\begin{array}{l}\text { NR } \\
(0.04)\end{array}$ & $\begin{array}{l}108 \\
125\end{array}$ & $\begin{array}{l}\text { NR } \\
0.53\end{array}$ & $\begin{array}{l}74 \\
75\end{array}$ \\
\hline
\end{tabular}

A: doxorubicin. C: cyclophosphamide. D: docetaxel. F: fluorouracil. P: paclitaxel. E: epirubicin. M: methotrexate. S: surgery. OS: overall survival. DFS: disease free survival. HR: hazard ratio. NS: not significant. NR: not reported.

Table 3. Clinical trials in the adjuvant treatment of early breast cancer using taxanes sequentially with similar treatment duration.

\begin{tabular}{|c|c|c|c|c|c|c|c|}
\hline Trial ( $n^{\circ}$ patients) & $\begin{array}{c}\mathbf{N} \\
\text { status }\end{array}$ & $\begin{array}{l}\text { Follow up } \\
\text { (months) }\end{array}$ & Design & $\begin{array}{c}\text { HR for } \\
\text { DFS } \\
\text { (p value) } \\
\end{array}$ & $\begin{array}{l}\text { Events for } \\
\text { DFS }\end{array}$ & $\begin{array}{l}\text { HR for OS } \\
\text { (p value) }\end{array}$ & $\mathbf{N}^{\circ}$ deaths \\
\hline PACS 01, $2006(1999)^{11}$ & + & 60 & $\begin{array}{l}\mathrm{FEC} \rightarrow \mathrm{D}(1003) \\
\text { FEC }(996)\end{array}$ & $\begin{array}{c}0.80 \\
(0.012)\end{array}$ & $\begin{array}{l}218 \\
264\end{array}$ & $\begin{array}{c}0.73 \\
(0.017)\end{array}$ & $\begin{array}{l}100 \\
135\end{array}$ \\
\hline MA21, $2010(2104)^{19}$ & $+/-$ & 30.4 & $\begin{array}{c}\mathrm{AC} \rightarrow \mathrm{P}(702)(\mathrm{i}) \\
\mathrm{ddEC} \rightarrow \mathrm{P}(701)(\mathrm{ii}) \\
\mathrm{CEF}(701) \text { (iii) }\end{array}$ & $\begin{array}{l}\text { i vs. ii } 1.49 \\
\quad(0.005) \\
\text { ii vs. iii } 0.89 \\
\quad(0.46)\end{array}$ & $\begin{array}{c}112 \\
70 \\
79\end{array}$ & NR & $\begin{array}{l}65 \\
47 \\
50\end{array}$ \\
\hline $\begin{array}{l}\text { GEICAM 9906, } 2008 \\
(1246)^{12}\end{array}$ & + & 66 & $\begin{array}{c}\mathrm{FEC} \rightarrow \mathrm{P}(614) \\
\mathrm{FEC}(632)\end{array}$ & $\begin{array}{c}0.77 \\
(0.02)\end{array}$ & $\begin{array}{l}146 \\
193\end{array}$ & $\begin{array}{c}0.78 \\
(0.11)\end{array}$ & $\begin{array}{l}73 \\
95\end{array}$ \\
\hline TACT, $2008(4162)^{20}$ & $+1-$ & 62 & $\begin{array}{c}\mathrm{FEC} \rightarrow \mathrm{D}(2073) \\
\mathrm{FEC} / \mathrm{E} \rightarrow \mathrm{CMF} \\
(2089)\end{array}$ & $\begin{array}{c}0.95 \\
(0.44)\end{array}$ & $\begin{array}{l}517 \\
539\end{array}$ & $\begin{array}{c}0.99 \\
(0.91)\end{array}$ & $\begin{array}{l}374 \\
378\end{array}$ \\
\hline
\end{tabular}

A: doxorubicin. C: cyclophosphamide. D: docetaxel. dd: dose dense. F: fluorouracil. P: paclitaxel. E: epirubicin. M: methotrexate. OS: overall survival. DFS: disease free survival. HR: hazard ratio. NR: not reported.

pausal women were treated with tamoxifen regardless of receptor status, but this was later extended to pre-menopausal women with positive hormone receptor status. So hormone receptor status is insufficient alone and is not the only predictive factor for taxane efficacy.

Hayes et al. [22] reported in their study on 1500 patients from the CALGB 9344 trial how the addition of paclitaxel to adjuvant therapy with doxorubicin plus cyclophosphamide was associated with significantly lower relapse and mortality rates in Her2 positive patients, regardless of ER expression status. An interesting finding here is that the group of patients with Her2 negative, ER positive breast cancer, i.e. over half the patients with breast cancer included in the trial, did not gain any benefit from the addition of paclitaxel. However, these outcomes do belong to an unplanned retrospective analysis of patient subgroups and while the result of such a study is useful to generate hypotheses, we cannot draw definitive conclusions. Therefore, these results should be confirmed prospectively before they become a turning point for a change in clinical practice.

We may conclude that taxanes afford a modest increase in overall survival in breast cancer patients regardless of how they are given. This may well be due to the fact that the gain is not seen homogeneously across all patients, and becomes even weaker among women where this therapy is of no advantage given the heterogeneity of breast cancer as a disease. Unfortunately, we have no factors capable of predicting the benefit of taxanes that could be applied in clinical practice so as to 
optimize their use. Hormone receptor expression and Her2 status alone have scant predictive value for the efficacy of taxanes. Translational trials, like the Trans TACT trial, are of the utmost interest and the knowledge generated may well help to improve patient selection in the future [20].

\section{REFERENCES}

[1] T. Ferguson, N. Wilcken, R. Vagg, D. Ghersi and A. K. Nowak, "Taxanes for Adjuvant Treatment of Early Breast Cancer,” Cochrane Review, Vol. 17, No. 4, 2007, p. 4421. doi:10.1002/14651858.

[2] M. De Laurentiis, G. Arpino and E. Massarelli, et al., "A Meta-Analysis on the Interaction between HER-2 Expression and Response to Endocrine Treatment in Advanced Breast Cancer," Clinical Cancer Research, Vol. 17, No. 15, 2005, pp. 4741-4748. doi:10.1158/1078-0432.CCR-04-2569

[3] M. Martin, T. Pienkowski and J. Mackey, et al., "Adjuvant Docetaxel for Node-Positive Breast Cancer," The New England Journal of Medicine, Vol. 352, 2005, pp. 2302-2313. doi:10.1056/NEJMoa043681

[4] P. Francis, J. Crown, A. Di Leo and M. Buyse, et al., "Adjuvant Chemotherapy with Sequential or Concurrent Anthracycline and Docetaxel: Breast International Group 02-98 Randomized Trial," Journal of the National Cancer Institution, Vol. 100, No. 2, 2008, pp. 121-133. doi:10.1093/jnci/djm287

[5] M. Martin, A. Lluch and M. A. Segui, et al., "TAC versus FAC as Adjuvant Chemotherapy for High-Risk NodeNegative Breast Cancer: Results of the GEICAM 9805 Trial,” Annual Oncology, Vol. 19, 2008, p. 1830.

[6] S. Jones, F. A. Holmes and J. O’Shaughnessy, “Docetaxel with Cyclophosphamide Is Associated with an Overall Survival Benefit Compared with Doxorubicin and Cyclophosphamide: 7-Year Follow-up of US Oncology Research Trial 9735," Journal of Clinical Oncology, Vol. 27, No. 8, 2009, pp. 1177-1183. doi:10.1200/JCO.2008.18.4028

[7] I. C. Henderson, D. A. Berry and G. D. Demetri, "Improved Outcomes from Adding Sequential Paclitaxel but not from Escalating Doxorubicin Dose in an Adjuvant Chemotherapy Regimen for Patients with Node-Positive Primary Breast Cancer," Journal of Clinical Oncology, Vol. 21, No. 6, 2003, pp. 976-983. doi:10.1200/JCO.2003.02.063

[8] E. P. Mamounas, J. Bryant and B. Lembersky, "Paclitaxel after Doxorubicin plus Cyclophosphamide as Adjuvant Chemotherapy for Node-Positive Breast Cancer: Results from NSABP B-28,” Journal of Clinical Oncology, Vol. 23, No. 16, 2005, pp. 3686-3696. doi:10.1200/JCO.2005.10.517

[9] L. Gianni, J. Baselga and W. Eiermann, et al., "Phase III Trial Evaluating the Addition of Paclitaxel to Doxorubicin Followed by Cyclophosphamide, Methotrexate, and Fluorouracil, as Adjuvant or Primary Systemic Therapy: European Cooperative Trial in Operable Breast Cancer,”
Journal of Clinical Oncology, Vol. 27, No. 15, 2009, pp. 2474-2481. doi:10.1200/JCO.2008.19.2567

[10] A. Polyzos, N. Malamos and I. Boukovinas, et al., "FEC versus Sequential Docetaxel Followed by Epirubicin/ Cyclophosphamide as Adjuvant Chemotherapy in Women with Axillary Node-Positive Early Breast Cancer: A Randomized Study of the Hellenic Oncology Research Group (HORG),” Breast Cancer Research and Treatment, Vol. 119, No. 1, 2010, pp. 95-104. doi:10.1007/s10549-009-0468-0

[11] H. Roche, P. Fumoleau and M. Spielmann, "Sequential Adjuvant Epirubicin-Based and Docetaxel Chemotherapy for Node-Positive Breast Cancer Patients: The FNCLCC PACS 01 Trial,” Journal of Clinical Oncology, Vol. 24, No. 36, 2006, pp. 5664-5671. doi:10.1200/JCO.2006.07.3916

[12] M. Martin, A. Rodriguez-Lescure and A. Ruiz, "Randomized Phase 3 Trial of Fluorouracil, Epirubicin, and Cyclophosphamide Alone or Followed by Paclitaxel for Early Breast Cancer,” Journal of the National Cancer Institution, Vol. 100, No. 11, 2008, pp. 805-814. doi:10.1093/jnci/djn151

[13] T. R. Evans, A. Yellowlees and E. Foster, et al., "Phase III Randomized Trial of Doxorubicin and Docetaxel versus Doxorubicin and Cyclophosphamide as Primary Medical Therapy in Women with Breast Cancer: An Anglo-Celtic Cooperative Oncology Group Study,” Journal of Clinical Oncology, Vol. 23, No. 13, 2005, pp. 2988-2895. doi:10.1200/JCO.2005.06.156

[14] L. J. Goldstein, A. O’Neill and J. A. Sparano, et al., "Concurrent Doxorubicin Plus Docetaxel is not More Effective than Concurrent Doxorubicin Plus Cyclophosphamide in Operable Breast Cancer with 0 to 3 Positive Axillary Nodes: North American Breast Cancer Intergroup Trial E 2197,” Journal of Clinical Oncology, Vol. 26, No. 25, 2008, pp. 4092-4099. doi:10.1200/JCO.2008.16.7841

[15] A. U. Buzdar, S. E. Singletary and V. Valero, et al., "Evaluation of Paclitaxel in Adjuvant Chemotherapy for Patients with Operable Breast Cancer: Preliminary Data of a Prospective Randomized Trial," Clinical Cancer Research, Vol. 8, 2002, pp. 1073-1079.

[16] G. Fountzilas, D. Skarlos and U. Dafni, "Postoperative Dose-Dense Sequential Chemotherapy with Epirubicin, Followed by CMF with or without Paclitaxel, in Patients with High-Risk Operable Breast Cancer: A Randomized Phase III Study Conducted by the Hellenic Cooperative Oncology Group,” Annals of Oncology, Vol. 16, No. 11, 2005, pp. 1762-1771. doi:10.1093/annonc/mdi366

[17] H. D. Bear, S. Anderson and R. E. Smith, et al., "Sequential Preoperative or Postoperative Docetaxel Added to Preoperative Doxorubicin Plus Cyclophosphamide for Operable Breast Cancer: National Surgical Adjuvant Breast and Bowel Project Protocol B-27," Journal of Clinical Oncology, Vol. 24, No. 13, 2006, pp. 2019-2027. doi:10.1200/JCO.2005.04.1665

[18] A. R. Bianco, A. De Matteis and L. Manzione, "Sequential Epirubicin-Docetaxel-CMF as Adjuvant Therapy of 
Early Breast Cancer: Results of the Taxit216 Multicenter Phase III Trial,” Journal of Clinical Oncology, Vol. 24, No. 18, 2006, p. 520.

[19] M. J. Burnell, M. N. Levine and J. A. Chapman, et al., "Cyclophosphamide, Epirubicin, and Fluorouracil Versus Dose-Dense Epirubicin and Cyclophosphamide Followed by Paclitaxel versus Doxorubicin and Cyclophosphamide Followed by Paclitaxel in Node-Positive or High-Risk Node-Negative Breast Cancer," Journal of Clinical Oncology, Vol. 28, No. 1, 2010, pp. 77-82. doi:10.1200/JCO.2009.22.1077

[20] P. Ellis, P. Barrett-Lee and L. Johnson, et al., "Sequential Docetaxel as Adjuvant Chemotherapy for Early Breast
Cancer (TACT): An Open-Label, Phase III, Randomised Controlled Trial,” Lancet, Vol. 373, 2009, pp. 1681-1692. doi:10.1016/S0140-6736(09)60740-6

[21] D. A. Berry, C. Cirrincione and I. G. Henderson, et al., "Estrogen Receptor Status and Outcomes of Modern Chemotherapy for Patients with Node-Positive Breast Cancer," The Journal of the American Medical Association, Vol. 295, No. 14, 2006, pp. 1658-1667. doi:10.1001/jama.295.14.1658

[22] D. F. Hayes, A. D. Thor and L. G. Dressler, et al., "Her2 and Response to Paclitaxel in Node Positive Breast Cancer," The New England Journal of Medicine, Vol. 357, 2007, pp. 1496-1506. doi.org/10.1056/NEJMoa071167 